\title{
Pengaruh Pelatihan dan Disiplin Kerja terhadap Prestasi Kerja Karyawan
}

\author{
R. Allail ${ }^{1}$, Sumiyati \& R. Purnama \\ Universitas Pendidikan Indonesia \\ rifal.allail@student.upi.edu
}

\begin{abstract}
The purpose of this study was to determine how much influence the training on work performance, work discipline on work performance and training and work discipline on employee work performance The type of research used was descriptive, verification, with a total sample of 80 employees. The data analysis technique used is path analysis The findings from the research on hypothesis testing can be seen that training and work discipline have a positive influence / large category on employee work performance. The originality of this research is the difference found in the object of research, the period of research, the measurement tools and the results of the study.
\end{abstract}

\footnotetext{
ABSTRAK

Tujuan penelitian ini adalah untuk mengetahui seberapa besar pengaruh pelatihan terhadap prestasi kerja, disiplin kerja terhadap prestasi kerja dan pelatihan dan disiplin kerja terhadap prestasi kerja karyawan Jenis penelitian yang digunakan adala deskriptif, verifikatif, dengan jumlah sampel sebanyak 80 karyawan. Teknik analisa data yang digunakan adalah path analisis Temuan dari penelitian terhadap pengujian hipotesis dapat diketahui bahwa pelatihan dan disiplin kerja memiliki pengaruh yang positif/katergori besar terhadap prestasi kerja karyawan. Orisinalitas dari penelitian ini adalah Perbedaan yang ditemukan dalam objek penelitian, periode penelitian, alat ukur dan hasil penelitian. Penulis juga menambahkan teori dari jurnal asing dan buku asing
}

\author{
ARTICLE INFO: \\ Article history: \\ Received 3 February 2017 \\ Revised 3 February 2017 \\ Accepted 4 February 2017 \\ Available online 20 May \\ 2017
}

\section{Keywords:}

Work Discipline, Training, Work Achievement, Management, Human Resources

\section{Kata Kunci: \\ Disiplin Kerja, , Pelatihan, Prestasi Kerja, Manajemen, Sumber Daya Manusia}

\section{PENDAHULUAN}

Keberhasilan suatu perusahaan atau organisasi sangat ditentukan oleh kegiatan pendayagunaan sumber daya manusia yaitu orang-orang yang menyediakan tenaga, bakat, kreativitas dan semangat bagi perusahaan serta memegang peranan penting dalam fungsi operasional perusahaan. Walaupun perusahaan memiliki teknologi yang modern, perusahaan tetap tidak akan terlepas dari tenaga kerja manusia, sebab bagaimanapun majunya suatu teknologi tanpa ditunjang oleh kemampuan manusia sebagai sumber dayanya maka tujuan perusahaan tidak akan pernah tercapai.
Kemajuan suatu perusahaan ditentukan oleh kualitas sumber daya manusia yang dimilikinya, sehingga sangatlah penting bagi suatu perusahaan untuk memperhatikan kualitas sumber daya manusia yang dalam hal ini adalah karyawannya. Mempersiapkan sumber daya manusia untuk menghadapi masa depan yang penuh dengan tantangan global dan perubahan teknologi yang semakin pesat, dengan membangun dan mengembangkan keahlian serta kemampuan, yang pada akhirnya akan meningkatkan kualitas sumber daya manusia itu sendiri(Senen, 2013). 
Perusahaan yang memiliki personel yang lebih baik, adalah perusahaan yang akan memenangkan persaingan. Keberadaan manusia sebagai sumber daya manusia adalah sangat penting dalam organisasi karena sumber daya manusia menunjang organsiasi melalui karya, bakat, kreativitas, dorongan dan peran nyata seperti yang dapat dilihat dalam setiap organisasi. Tanpa adanya unsur manusia dalam sebuah organisasi, tidak mungkin organisasi tersebut dapat bergerak dan menuju yang diinginkan(Masharyono, 2015).

Rendahnya prestasi kerja karyawan di PT. Tandur Niaga Bersama (TIKI) Bandung mengakibatkan penurunan tingkat produksi pengiriman paket. Terdapat beberapa faktor yang dapat mempengaruhi prestasi kerja karyawan, Sutrisno mengungkapkan bahwa faktor-faktor yang mempengaruhi prestasi kerja antara lain adalah kepemimpinan, lingkungan kerja, disiplin kerja, motivasi kerja, pendidikan dan pelatihan kerja.(Sutrisno, 2013a).

Dalam upaya meningkatkan prestasi kerja karyawan, PT. Tandur Niaga Bersama melakukan berbagai cara, pemberian insentif, penghargaan, jaminan keselamatan kerja, pelatihan dan pengembangan karier, rotasi karyawan, penghargaan secara imateril seperti pujian, pengawasan, memberikan sanksi kepada karyawan yang indispliner, melakukan evaluasi kerja, hingga pemutusan pemutusan hubungan kerja. Seluruh usaha yang dilakukan oleh PT. Tandur Niaga Bersama untuk meningkatkan prestasi kerja karyawannya memiliki hasil yang positif. Strategi-strategi yang dilakukan oleh PT. Tandur Niaga Bersama tersebut meningkatkan prestasi para karyawan, namun dengan presentasi keberhasilan yang berbeda.

Pelatihan merupakan sasaran utama yang harus diupayakan perusahaan dalam meningkatkan prestasi kerja karyawannya, agar dalam dirinya timbul suatu semangat yang tinggi dalam setiap pelaksanaan aktivitas kerjanya. T.Hani Handoko berpendapat bahwa, "Prestasi kerja yang jelek mungkin menunjukan kebutuhan latihan. Demikian juga, prestasi yang baik mungkin mencerminkan potensi yang harus dikembangkan"(Handoko, 2011).

Dilani Jayawarna, et.al (2007) dalam jurnalnya mengemukakan bahwa "Pengembangan sumber daya manusia dapat dilakukan melalui banyak cara. Dua diantara yang sangat penting bagi pengembangan sumber daya manusia adalah melalui pendidikan dan pelatihan karyawan dapat diperoleh secara formal, informal ataupun non formal'(Jayawarna, 2007).

Selain pelatihan, kebijakan lain yang dilakukan oleh PT. Tandur Niaga Bersama yaitu peningkatan disiplin kerja karyawan. Berdasarkan hasil wawancara dengan Kristianta Ginting.SH selaku manager HRD PT. Tandur Niaga Bersama, kondisi sebagian pegawai tidak menaati peraturan yang ditetapkan oleh perusahaan, hal ini terlihat dengan masih adanya pegawai yang masuk terlambat kerja, pulang tidak sesuai waktu, selain itu pegawai sering mengulur waktu istirahat, masih adanya perilaku pegawai yang tidak menaati peraturan perusahaan. Apabila hal ini terus-menerus, maka dapat merugikan bagi perusahaan. Disiplin kerja dapat mempengaruhi kinerja pegawai, pernyataan ini diperkuat dengan adanya pendapat dari Malayu S.P Hasibuan "Semakin baik disiplin kerja seseorang, maka semakin tinggi hasil prestasi kerja (kinerja) yang akan dicapai"(Hasibuan, 2012).

Berdasarkan latar belakang di atas, maka perlu dilakukan sebuah penelitian tentang, "Pengaruh Pelatihan dan Disiplin Kerja Terhadap Prestasi Kerja Karyawan Di PT. Tandur Niaga Bersama (TIKI) Bandung".

Adapun tujuan penelitian ini adalah Pelatihan dan Disiplin Kerja Terhadap Prestasi Kerja Karyawan Di PT. Tandur Niaga Bersama (TIKI) Bandung. 


\section{KAJIAN PUSTAKA}

Menurut Veithzal Rivai, pelatihan adalah proses secara sistematis mengubah tingkah laku pegawai untuk mencapai tujuan organisasi (Veithzal, 2013). Selain pendapat tersebut menurut Byars dan Leslie mengungkapkan bahwa pelatihan adalah, " $a$ learning process that involves the aquisition of skill, concept, rules, or attitudes to enchance emplyee performance" (Byars, 2000). Menurut pendapat para ahli tersebut, dapat dikatakan bahwa pelatihan merupakan tempat dimana karyawan melaksanakan latihan dengan cara memperbaiki penguasaan berbagai keterampilan dan teknik pelaksanaan kerja tertentu untuk memperoleh atau mempelajari sikap, kemauan, keahlian, pengetahuan, dan perilaku spesifik yang berkaitan dengan pekerjaan sekarang.

Bejo Siswanto Sastrohadiwiryo mengemukakan pendapatnya mengenai pengertian disiplin kerja adalah suatu sikap menghormati, menghargai, patuh dan taat terhadap peraturan-peraturan yang berlaku, baik yang tertulis maupun tidak tertulis serta sanggup menjalankannya dan tidak mengelak untuk menerima sanksi-sanksinya apabila ia melanggar tugas dan wewenang yang diberikan kepadanya(Sastrohadiwiryo, 2005). Disiplin kerja menurut Veithzal Rivai adalah suatu alat yang digunakan para manajer untuk berkomunikasi dengan karyawan agar mereka bersedia untuk mengubah suatu perilaku serta sebagai suatu upaya untuk meningkatkan kesadaran dan kesediaan seseorang mentaati semua peraturan perusahaan dan norma-norma sosial yang berlaku(Veithzal, 2013). Disiplin kerja adalah suatu sikap kesediaan karyawan dalam mematuhi dan mentaati segala peraturan yang dibuat perusahaan secara sukarela tanpa adanya paksaan(Mulyadi, 2010).
Berdasarkan pengertian yang telah dijelaskan sebelumnya, maka dapat dikatakan bahwa yang dimaksud dengan disiplin kerja adalah sikap mental yang tercermin dalam perbuatan perorangan maupun kelompok berupa kepatuhan atau ketaatan terhadap peraturan-peraturan yang ditetapkan untuk memperteguh pedoman-pedoman organisasi guna untuk mencapai tujuan perusahan dan apabila aturan tersebut dilanggar maka akan mendapatkan sanksi yang telah ditetapkan dan diharapkan dapat mengurangi kinerja yang buruk dari bagian dalam sebuah unit di dalam perusahaan.

A.A.Anwar Prabu Mangkunegara mengemukakan bahwa " prestasi kerja adalah hasil kerja secara kualitas dan kuantitas yang dicapai oleh seorang pegawai dalam melaksanakan tugasnya sesuai dengan tanggung jawab yang diberikan kepadanya"(Mangkunegara . A.Anwar Prabu, 2014). Kemudian menurut Michael Armstrong, secara konseptual mengemukakan tentang prestasi kerja adalah manajemen prestasi kerja didasarkan pada prinsip manajemen dengan menggunakan kontrak atau kesepakatan, bukan komando. Oleh karena itu, manajemen prestasi kerja didasarkan pada kesepakatan bersama mengenai tujuan, pengetahuan, keterampilan, syarat kompetensi, serta rencana kerja dan pengembangan sumber daya manusia yang bersangkutan. Manajemen prestasi kerja memerlukan telaah terusmenerus terhadap prestasi kerja dengan menggunakan parameter tujuan, syarat, dan rencana kerja, serta kesepakatan, perbaikan, dan rencana pengembangan karir masa depan(Amstrong, 2010). Selanjutnya menurut Malayu S.P Hasibuan menyatakan bahwa “ prestasi kerja adalah suatu hasil kerja yang dicapai seseorang dalam melaksanakan tugastugas yang dibebankan kepadanya yang didasarkan atas kecakapan, pengalaman, dan 
kesungguhan serta waktu“(Hasibuan, 2012). Hampir sejalan dengan pendapat Bernadian JH dan Joyce Russel (1993) dalam Sedarmayanti mendefinisikan prestasi kerja sebagai, “ catatan mengenai outcome yang dihasilkan dari suatu aktivitas tertentu, selama kurun waktu tertentu pula"(Sedarmayanti, 2014). Sedarmayanti mendefinisikan bahwa prestasi kerja adalah, " Hasil kerja yang dapat dicapai oleh seseorang atau sekelompok orang dalam suatu organisasi sesuai dengan wewenang dan tanggung jawab masing-masing dalam rangka upaya mencapai tujuan organisasi bersangkutan secara legal, tidak melanggar hukum dan sesuai dengan moral maupun etika"(Sedarmayanti, 2014). Sedangkan menurut Sutrisno, "Prestasi kerja adalah sebagai hasil kerja yang telah dicapai seseorang dari tingkah laku kerjanya dalam melaksanakan aktivitas kerja". Berdasarkan definisi para ahli tersebut maka dapat disimpulkan bahwa prestasi kerja adalah hasil kerja yang dicapai karyawannya secara kualitas maupun kuantitas dalam melaksanakan pekerjaan yang diberikan perusahaan pada karyawannya(Sutrisno, 2013).

\section{METODEPENELITIAN}

Penelitian ini menganalisis mengenai pengaruh pelatihan dan disiplin kerja terhadap prestasi kerja karyawan PT. Tandur Niaga Bersama (TIKI) Bandung. Dalam penelitian ini pelatihan sebagai variabel independent pertama memiliki dimensi yaitu reaction (reaksi), learning (pembelajaran), behavior (perilaku), dan result (hasil). Sedangkan disiplin kerja sebagai variabel independent kedua memiliki dimensi yaitu taat terhadap aturan waktu, taat terhadap aturan perusahaan, taat terhadap aturan perilaku dalam pekerjaan, taat terhadap peraturan lainnya. Variabel dependent dalam penelitian ini adalah prestasi kerja yang memiliki dimensi yaitu kualitas kerja, kauntitas kerja, inisiatif, dan tanggung jawab.

Penelitian ini dilakukan di PT. tandur Niaga Bersama (TIKI) Bandung. Berdasarkan pertimbangan tujuan penelitian, maka jenis penelitian ini adalah penelitian deskriptif dan penelitian verifikatif.

Penelitian deskriptif adalah penelitian yang bertujuan untuk memperoleh deskriptif tentang ciri-ciri variabel. Sedangkan sifat penelitian verifikatif pada dasarnya ingin menguji kebenaran suatu hipotesis yang dilaksanakan melalui pengumpulan data dilapangan (Purnama, 2008). Berdasarkan jenis penelitiannya, yakni deskriptif dan verifikatif yang dilaksanakan melalui pengumpulan data di lapangan, maka metode penelitian yang akan digunakan adalah metode explanatory survey (Wibowo, 2008). dengan teknik simple random sampling dengan jumlah responden sebanyak 80 orang. Teknik analisis yang digunakan dalam peneltian ini adalah path analysis . sedangkan teknik pengumpulan data yang digunakan adalah studi kepustakaan, observasi, wawancara, dan kuesioner.

\section{HASIL DAN PEMBAHASAN}

Hasil penelitian mengenai pelatihan dan disiplin kerja terhadap prestasi kerja karyawan di PT. Tandur Niaga Bersama (TIKI) Bandung menghasilkan gambaran sebagai berikut:

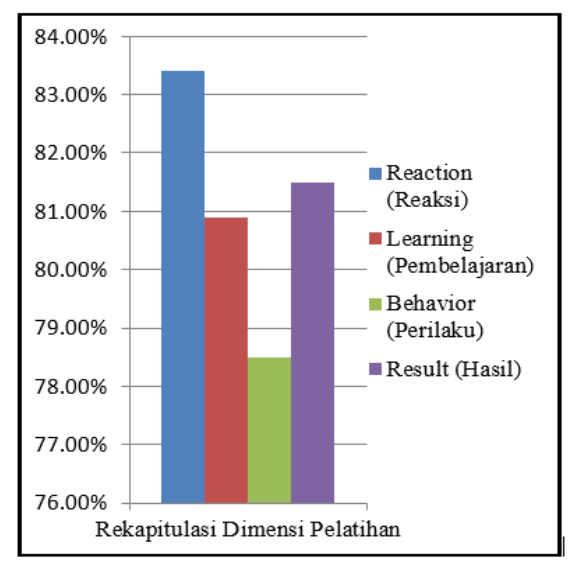

Gambar 1: Rekapitulasi Dimensi Pelatihan 
Dari keempat dimensi pelatihan, dimensi reaksi memperoleh total nilai tertinggi dengan skor $1400(83,4 \%)$. Hal tersebut menunjukan bahwa reaksi karyawan terhadap diadakannya pelatihan sangat baik. Sedangkan untuk dimensi yang memiliki skor terendah adalah dimensi perilaku dengan skor 1336 $(78,5 \%)$.

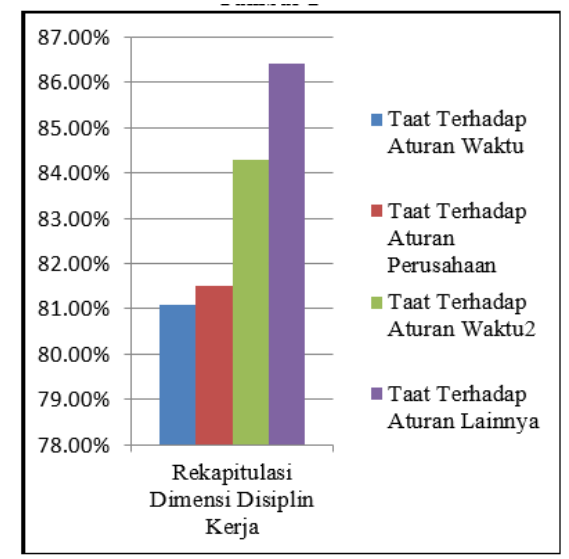

Gambar 2: Rekapitulasi Dimensi Kerja

Dari keempat dimensi disiplin kerja, dimensi yang memiliki presentase tertinggi yaitu dimensi Taat Terhadap Peraturan Lainnya dengan presentase sebesar 86,4\%, sedangkan yang memiliki presentase terendah yaitu dimensi Taat Terhadap Aturan Waktu dengan presentase $81,1 \%$. Hal tersebut menunjukan bahwa masih terdapat kekurangan pada ketaatan terhadap waktu sehingga perusahaan harus lebih meningkatkan disiplin pada dimensi waktu.

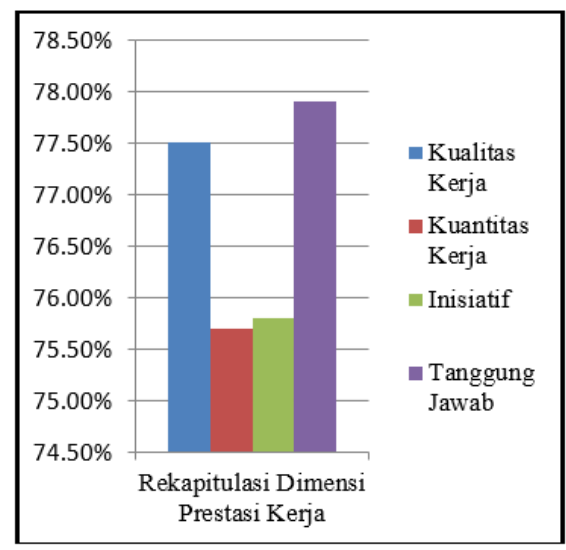

\section{Gambar 3: Rekapitulasi Dimensi Prestasi} Kerja

Dari keempat dimensi prestasi kerja, dimensi yang memiliki presentase tertinggi adalah dimensi tanggung jawab yaitu sebesar $77,9 \%$ dengan total skor 872 . Sedangkan skor terendah diperoleh oleh dimensi kuantitas kerja dengan total skor 848 atau apabila dipresentasikan yaitu sebesar 75,7\%. Hal tersebut menunjukan bahwa tanggung jawab karyawan sudah cukup baik namun masih memiliki kekurangan pada kuantitas kerja.

Hipotesis yang diuji dalam penelitian ini adalah pengaruh dari Pelatihan dan Disiplin Kerja terhadap Prestasi Kerja. Pengujian Parsial dapat dilakukan setelah dipastikan adanya pengaruh yang signifikan antara pelatihan dan disiplin kerja terhadap prestasi kerja melalui uji simultan.

Pengujian untuk uji F yang diambil dari Tabel Anova (terdapat dalam lampiran) dengan tingkat probabilitas $($ Sig) $=0,000$, karena nilai $\operatorname{Sig} \leq 0,05$ maka keputusannya adalah $\mathrm{H}_{0}$ ditolak dan $\mathrm{H}_{\mathrm{a}}$ diterima. Artinya secara simultan terdapat pengaruh yang positif antara pelatihan yang terdiri dari reaksi, pembelajaran, perilaku, hasil dan disiplin kerja yang terdiri dari taat terhadap aturan waktu, taat terhadap aturan perusahaan, taat terhadap aturan perilaku dalam pekerjaan, taat terhadap peraturan lainnya terhadap prestasi kerja yang terdiri dari kualitas kerja, kuantitas kerja, inisiatif, dan tanggung jawab.

Berdasarkan data, hubungan setiap variabel pelatihan, disiplin kerja , dan prestasi kerja. Berdasarkan hasil matriks korelasi antara pelatihan, disiplin kerja dan prestasi kerja diperoleh hasil korelasi secara berurutan yaitu pelatihan sebesar 0,805 , disiplin kerja sebesar 0,798. Variabel yang memiliki korelasi terbesar yaitu pelatihan dengan nilai korelasi sebesar 0,805 yang berarti memiliki hubungan sangat tinggi, hal ini dapat dikatakan bahwa pelatihan merupakan faktor yang paling memiliki hubungan dengan prestasi kerja karyawan sedangkan disiplin kerja memiliki 
korelasi terendah yaitu sebesar 0,798 dan memiliki hubungan sangat tinggi.

Pengaruh langsung maupun tidak langsung antara pelatihan dan disiplin kerja terhadap prestasi kerja yang paling besar pengaruhnya secara parsial yaitu pelatihan terhadap prestasi kerja sebesar $(0,372: 0,709) \mathrm{x}$ $100 \%=52,5 \%$ sedangkan pengaruh disiplin kerja terhadap prestasi kerja sebesar $(0,337: 0,709) \times 100 \%=47,5 \%$.

Melalui Tabel di atas juga dapat diketahui bahwa total koefisien jalur dari pelatihan dan disiplin kerja terhadap prestasi kerja adalah sebesar 0,709 sehingga dapat diketahui nilai dari koefisien residu adalah 0 , 539 .Hasil tersebut menunjukan bahwa pelatihan dan disiplin kerja secara simultan mempengaruhi terhadap prestasi kerja pada karyawan PT. Tandur Niaga Bersama yaitu sebesar $70,9 \%$ sedangkan pengaruh variabel lain yang tidak diteliti adalah $(0,539)^{2} \times 100 \%$ $=29,1 \%$

\section{KESIMPULAN DAN SARAN}

Berdasarkan uraian teori dan hasil penelitian yang telah dilakukan dengan menggunakan analisis deskriptif dan verifikatif serta uji path atau analisis jalur antara pelatihan dan disiplin kerja terhadap prestasi kerja karyawan PT. Tandur Niaga Bersama (TIKI) Bandung, dapat ditarik kesimpulan bahwa secara simultan (keseluruhan) terdapat pengaruh yang positif antara pengaruh pelatihan yang terdiri dari reaksi, pembelajaran, inisiatif, tanggung jawab dan disiplin kerja yang terdiri dari taat terhadap aturan waktu, taat terhadap aturan perusahaan, taat terhadap aturan perilaku dalam pekerjaan, taat terhadap peraturan lainnya terhadap prestasi kerja yang terdiri dari kualitas kerja, kuantitas kerja, inisiatif, dan tanggung jawab. Menunjukan bahwa pelatihan dan disiplin kerja berpengaruh secara positif terhadap prestasi kerja karyawan 


\section{DAFTAR PUSTAKA}

Amstrong, M. (2010). Human Resource Management. Great Britain and The United States: Kogan Page Limited.

Byars, L. (2000). Human Resource Management Sixth Edition. United States of America: The McGraw Hill Companies.

Handoko, T. H. (2011). Manajemen Personalia \& Sumber Daya Manusia. Yogyakarta: BPFE.

Hasibuan, M. S. . (2012). Manajemen Sumber Daya Manusia. Jakarta: PT. Bumi Aksara.

Jayawarna, D. (2007). Training Commitment and Performance in Manufacturing SMEs.

Mangkunegara . A.Anwar Prabu. (2014). Manajemen Sumber Daya Manusia Perusahaan. Bandung: Remaja Rosdakarya.

Masharyono. (2015). Characteristics Dalam Mendukung Universitas Pendidikan Indonesia Mencapai Leading and Ourstanding (Job Performance Analysis Temporary Employee Administative with Competence and Job Characteristics in Supporting Universitas Pendidikan Indonesia Leading), 120-137.

Mulyadi, H. (2010). Pengaruh Motivasi dan Disiplin Terhadap Kinerja Karyawan Pada Departemen Weaving PT. Adetex Cabang Banjaran Kab. Bandung.
Purnama, R. (2008). Pengaruh Program Event Family Gathering Terhadap Loyalitas Pelanggan Bisnis Pada Hotel Nuansa Bali Anyer, 84-100.

Sastrohadiwiryo, B. S. (2005). SastrohadiwiryoManajemen Tenaga Kerja Indonesia. Jakarta: Bumi Aksara.

Sedarmayanti. (2014). Sumber Daya Manusia dan Produktivitas Kerja. Bandung: CV Mandar Maju.

Senen, S. H. (2013). Pengaruh Motivasi Kerja dan Kemampuan Kerja Karyawan Terhadap Produktivitas Kerja Karyawan Pada PT. Safilindo Permata, 7(September), 1-15.

Sutrisno, E. (2013a). Manajemen Sumber Daya Manusia. Jakarta: Kencana Prenada.

. Sutrisno, E. (2013b). Manajemen Sumber Daya ManusiaManajemen Sumber Daya Manusia. Jakarta: Kencana Prenada Media Group.

Veithzal, R. (2013). Manajemen Sumber Daya Manusia untuk Perusahaan dari teori ke praktek. Jakarta: Raja Grafindo Persada.

Wibowo, L. A. (2008). Pengaruh Kinerja Kualitas Pelayanan Melalui Seven Romancing Moments Terhadap Pembelian Ulang Pada Restoran HokaHoka Bento Cabang Setiabudi Bandung, $1-11$ 